\title{
PENGARUH PENGEKANGAN GFRPTERHADAP KEKUATAN DAN DAKTILITAS KOLOM BETON BERTULANG PERSEGI AKIBAT BEBAN SIKLIK
}

\author{
Karmila Achmad ${ }^{1}$, Agoes $\mathrm{SMD}^{2}$ \& Tavio $^{3}$ \\ ${ }^{1}$ Mahasiswa Program Magister Teknik Sipil Struktur Universitas Brawijaya, Malang dan Dosen Politeknik Negeri \\ Balikpapan \\ ${ }^{2}$ Guru Besar Teknik Sipil Struktur Universitas Brawijaya, Malang \\ ${ }^{3}$ Dosen Teknik Sipil Struktur-FTSP Institut Teknologi Sepuluh Nopember, Surabaya \\ Email : milabpp@yahoo.co.id
}

\begin{abstract}
The aim of this research is to get improving of strength and ductility in column specimen given the GFRP strengthener (Glass Fiber Reinforced Polymer) toward with original column, by using the cyclic load as the fix representative of quake load. There are two specimens full scale used. They are C-1 (original column) and C-1G (column with GFRP strengthener 1 layer). From the research got $\mathrm{P}_{\text {max }}$ sequentially is $278,9 \mathrm{kN}$ and $372.4 \mathrm{kN}$, and $\mathrm{d}_{\max }$ is $53.24 \mathrm{~mm}$ and $56.78 \mathrm{~mm}$, each for C-1 and $\mathrm{C}-1 \mathrm{G}$. For $\mathrm{C}-1$ column, the concrete gets damage in plastic hinge zone at drift ratio $3.5 \%$ indicated by bending of longitudinal steel bar and spalling of cover concrete. The test for $\mathrm{C}-1 \mathrm{G}$ ends in third cycle at drift ratio 5\% and gets damage in fracture of GFRP in plastic hinge zone. The damage is the changing of resin color the circumferential direction in three spots. They are as long as 10,11 and $18 \mathrm{~cm}$. Ductility index taken on three positions are plastic hinge zone, column with a half high effective and as high as effective column. From the analyze result got ductility index C-1 on the three positions are $1.65 ; 1.70 ; 1,97$ and ductility index $\mathrm{C}-1 \mathrm{G}$ are 1,$44 ; 1,44$ and 1,38 each for plastic hinge zone, a half high effective and as high as effective column
\end{abstract}

Key words : ductility, GFRP, strength, external confinement, cyclic

\section{PENDAHULUAN}

Struktur kolom merupakan elemen struktur yang rentan terhadap kegagalan ketika menerima beban yang besar (ledakan atau seismik), peningkatan beban (meningkatkan penggunaan atau perubahan fungsi struktur) dan degradasi kekuatan (akibat korosi tulangan baja dan reaksi alkali). Sebagaimana diketahui bahwa kolom merupakan elemen struktur yang penting karena kegagalan kolom akan berakibat langsung terhadap komponen struktur lainnya. Sehingga dalam suatu struktur keruntuhan kolom struktural merupakan hal yang sangat penting untuk ditinjau.

Dua hal penting yang harus diperhatikan dalam mendesain struktur adalah kekuatan, yang terkait dengan peningkatan beban dan daktilitas sebagai persyaratan dasar pada struktur yang menahan pembebanan dinamis, seperti gempa bumi. Dimana pembebanan siklik merupakan representatif yang tepat untuk menggambarkan beban dinamis yang terjadi.
Penelitian ini memanfaatkan kemajuan teknologi berupa penggunaan material Glass Fiber Reinforced Polymer (GFRP) untuk perkuatan eksternal kolom. Sehingga didapatkan struktur kolom yang memiliki kekuatan dan daktilitas yang tinggi.

Dalam makalah ini, meskipun hasil penelitian belum maksimal namun diharapkan dapat memberikan informasi yang bermanfaat terhadap penggunaan GFRP pada struktur diwilayah gempa yang mengalami peningkatan beban.

\section{Glass Fiber Reinforced Polymer (GFRP)}

Fiber Reinforced Polymer (FRP) adalah inovasi perkuatan komposit yang saat ini banyak digunakan sebagai perkuatan eksternal tambahan pada struktur karena sifatnya setelah dipasang pada struktur beton mampu menghilangkan kekurangan beton yang getas menjadi struktur yang ductile. ${ }^{5}$ Keunggulan dari perkuatan FRP ini yaitu bahan lebih ringan, kekuatan tarik tinggi, tidak terjadi korosi sehingga memiliki 
durabilitas (keawetan) yang tinggi, mudah dalam pemasangannya sehingga menghemat waktu serta bahannya mudah untuk dibentuk (fleksibel). Dua jenis serat yang umum digunakan untuk perkuatan struktur adalah: Glass Fiber Reinforced Polymer (GFRP) dan Carbon Fiber Reinforced Polymer (CFRP).

GFRP adalah jenis fiber yang relatif lebih murah serta memiliki regangan yang lebih besar dibandingkan CFRP. Keunggulan GFRP lainnya adalah ketahanan kimia yang sangat tinggi dan memiliki sifat isolasi yang sangat baik. Keunggulan ini menjadikan material GFRP merupakan pilihan yang baik untuk perkuatan struktur.

Gambar 1. Tyfo ${ }^{\hat{a}}$ SEH System Uni-directional glass composite

\section{Eksternal confinement}

Konsep confinement adalah untuk menahan beton dan menunda kegagalan. Confinement dapat didefinisikan sebagai pembatasan pelebaran lateral beton. Sehingga diharapkan dengan adanya pengekangan yang baik pada struktur maka mampu meningkatkan kekuatan tekan dan regangan aksial ultimit.

Sama dengan pengekangan internal maka tujuan pengekangan eksternal FRP pada struktur adalah untuk meningkatkan kekuatan dan daktilitasnya. Perbedaan ada pada posisi confinement itu sendiri.

Dalam penelitian ini pengekangan dilakukan pada penampang persegi. Pada gambar 2 menunjukkan bentuk dari bagian yang terkekang untuk dimensi $B \times H$ dan jari-jari sudut $r$. Daerah tidak terkekang umumnya diwakili oleh empat parabola (fungsi kuadrat) dengan kemiringan awal adalah 45 derajat. Untuk mencegah overlap parabola ketika penampang persegi panjang memiliki aspek rasio tinggi, Lam dan Tengmengusulkan bahwa lereng awal dari parabola adalah sama dengan lereng diagonal dari dimensi $B \times H$.

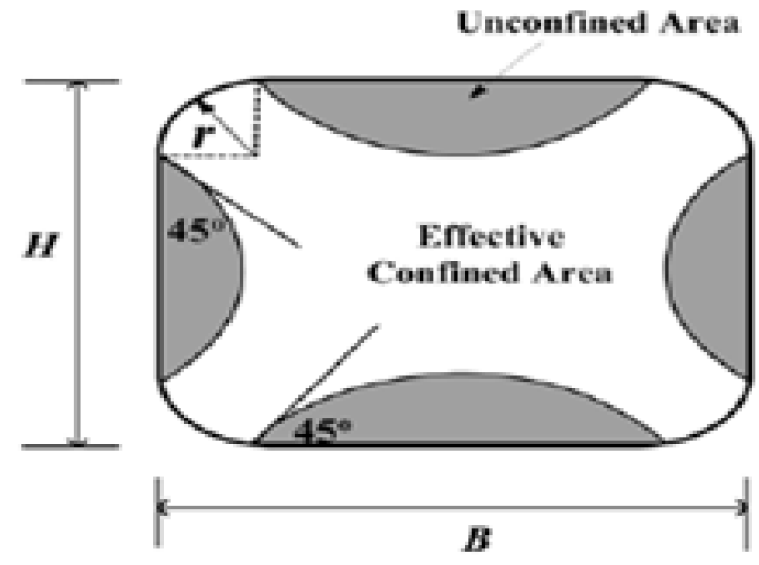

Gambar 2. Gaya kekang pada penampang beton $^{10}$

\section{Kekuatan}

Kapasitas (nominal) beban aksial teoritis dari kolom nonslender perkuatan FRP adalah :

$$
P_{0}=0,85 \psi_{f} f_{c c}^{\prime}\left(A_{g}-A_{s t}\right)+f_{y} A_{s t}
$$

Dimana:

$A_{g}=$ luas bruto beton

$A_{s t}=$ luasan tulangan memanjang baja

$f_{y}=$ tegangan leleh baja longitudinal

$y_{f}=$ faktor reduksi FRP

$f^{\prime}{ }_{c c}=$ kuat tekan beton terkekang

Kapasitas aksial nominal maksimum kolom nonslender perkuatan FRP dengan pengekangan tied adalah:

$P_{n(\text { maks })}=0,80\left[0,85 \psi_{f} f_{c c}^{\prime}\left(A_{g}-A_{s t}\right)+f_{y} A_{s t}\right]$

Menurut ACI 440.2R-02 kekuatan tekan pengekangan, $f_{c c}^{\prime}$ yang merupakan persamaan kekuatan beton terkekang yang dikembangkan oleh Mander dkk (1988) adalah:

$$
f_{c c}^{\prime}=f_{c}^{\prime}\left(2,25 \sqrt{1+7,9 \frac{f_{l}}{f_{c}^{\prime}}}-2 \frac{f_{l}}{f_{c}^{\prime}}-1,25\right)
$$




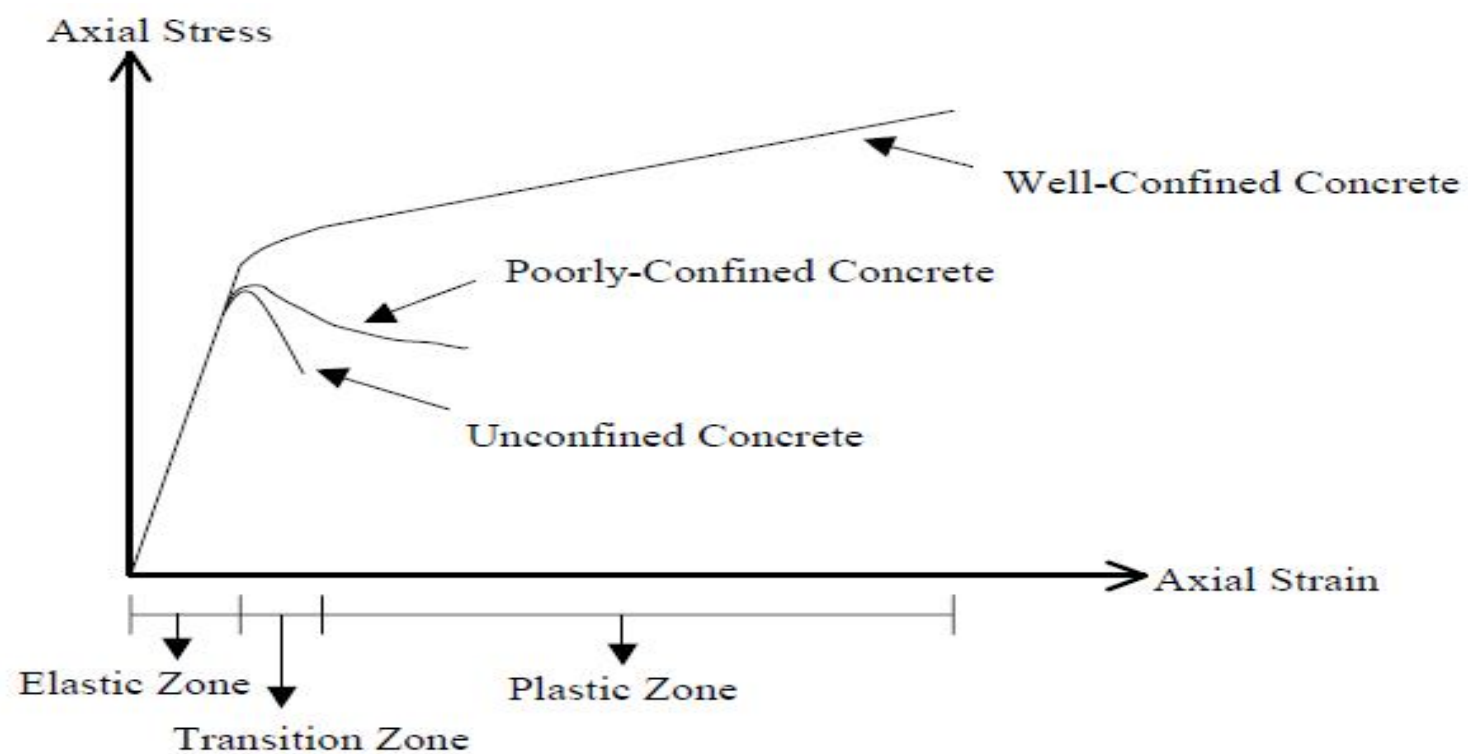

Gambar 3. Kurva tegangan-regangan untuk beton terkekang dan tidak terkekang ${ }^{8}$

\section{Daktilitas}

Struktur yang mampu menahan deformasi plastis yang besar dikatakan ductile. Struktur yang mampu menahan deformasi plastis yang kecil sebelum hancur dikatakan brittle. Parameter daktilitas yang digunakan adalah Momen (M) dan Curvature (j).

Perilaku pasca puncak karena spalling selimut beton dan tekuk tulangan longitudinal akan memberikan pengaruh yang signifikan pada deformasi dan daktilitas struktur.

$$
\mu=\frac{\varphi_{u}}{\varphi_{y}}
$$

Dimana :

$\mathrm{m}=$ indeks daktilitas

$\mathrm{ju}=$ curvature ultimit $\left(\mathrm{m}^{-1}\right)$

$\mathrm{jy}=$ curvature leleh $\left(\mathrm{m}^{-1}\right)$

\section{Beban Siklik}

Beban siklik merupakan beban berulang yang diterima oleh suatu struktur. Kekuatanfatigue akibat beban siklik dipengaruhi oleh berbagai pembebanan, tingkat pembebanan, load history dan sifat material. ${ }^{4}$ Untuk memprediksi perilaku struktur maka histeresis loop adalah hal yang penting untuk diamati. ${ }^{20}$
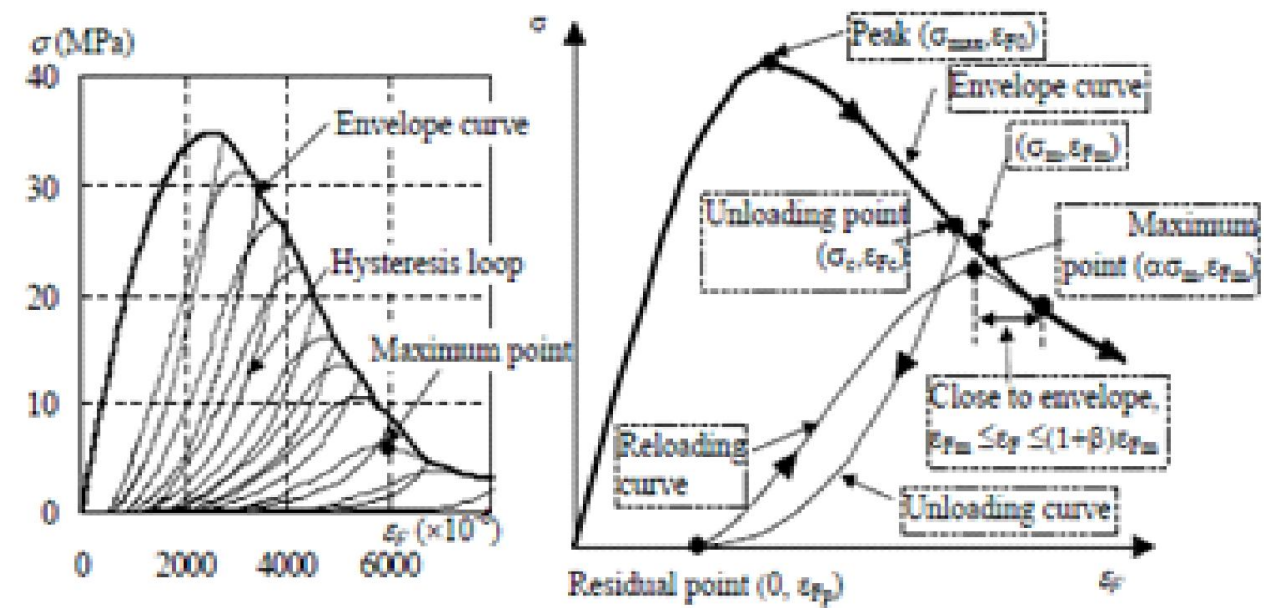

Gambar 4. Histeresis loop $^{21}$ 


\section{METODOLOGI PENELITIAN}

\section{Specimen}

Specimen yang diuji adalah kolom persegi dengan ukuran 350 x $350 \mathrm{~mm}$ dan tinggi efektif $1100 \mathrm{~mm}$. Pada bagian bawah kolom dijepit dengan pelat baja setinggi $500 \mathrm{~mm}$. Mutu beton yang digunakan adalah
20,34 MPa, mutu baja adalah 549,94 MPa dan tegangan tarik GFRP adalah 510,48 MPa.

Dalam penelitian ini digunakan 2 buah specimen yaitu kolom original adalah kolom tanpa perkuatan fiber (C-1) dan kolom dengan 1 lapis GFRP (C-1G). Jumlah tulangan longitudinal 8D19 dan jarak antar sengkang f10-200. Detail gambar seperti pada gambar 5 .

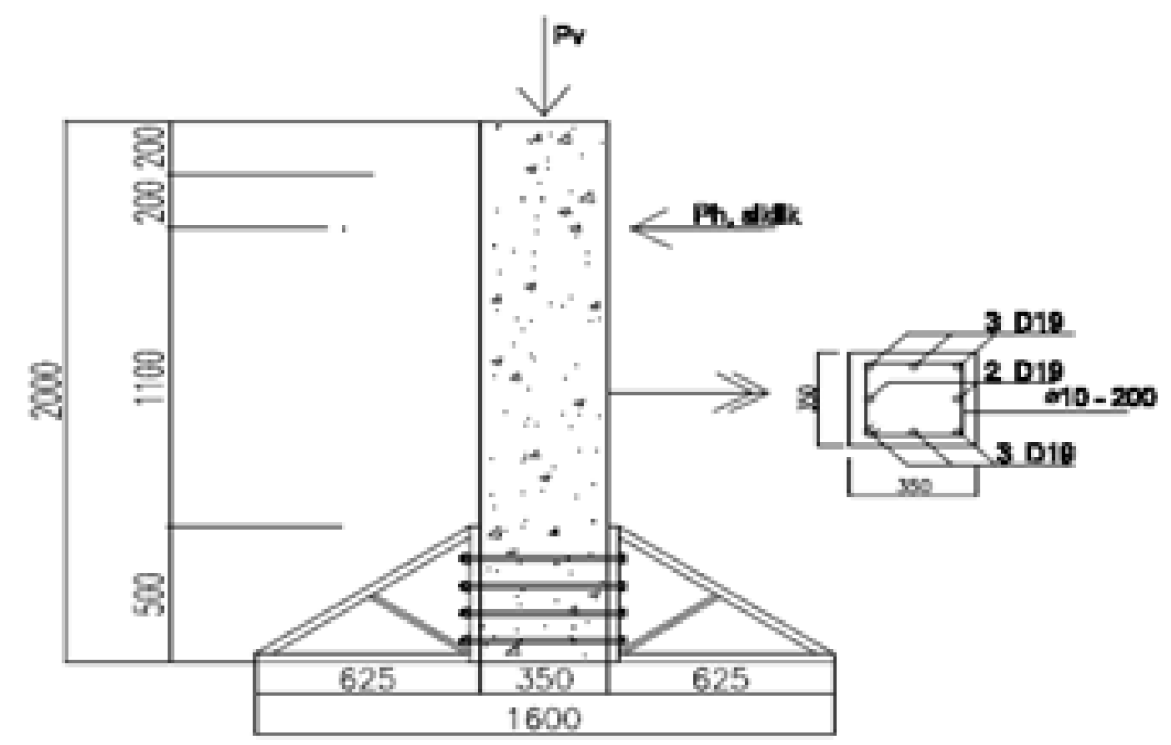

(a)

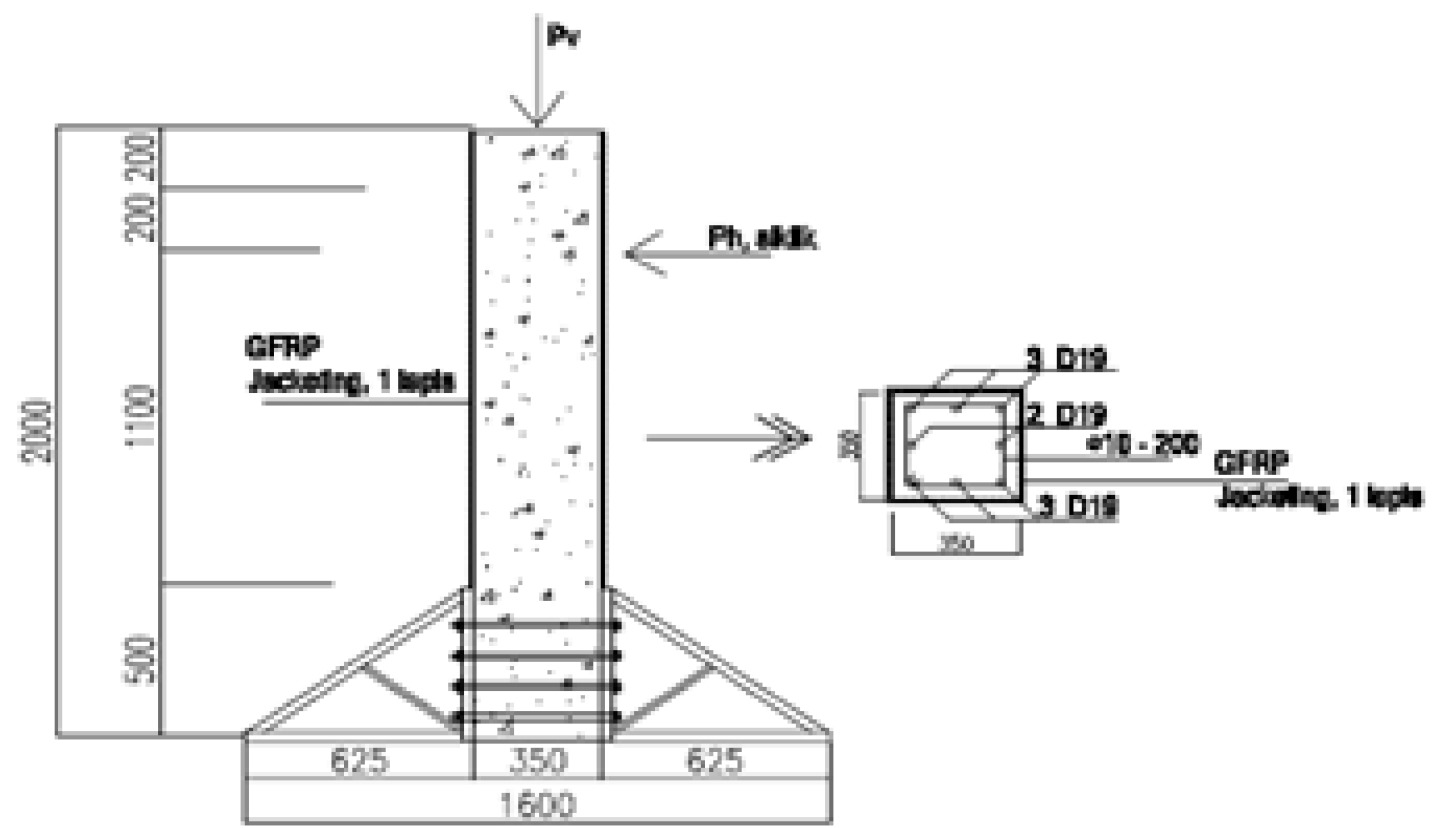

(b)

\section{Aplikasi Strain Gauge}

Dalam pengujian ini masing-masing specimen akan menggunakan 8 strain gauge tulangan baja, 2

\section{Gambar 5. Specimen: (a)C-1; (b)C-1G}

strain gauge fiber untuk $C-1 G$ dan 2 strain gauge beton untuk C-1. 

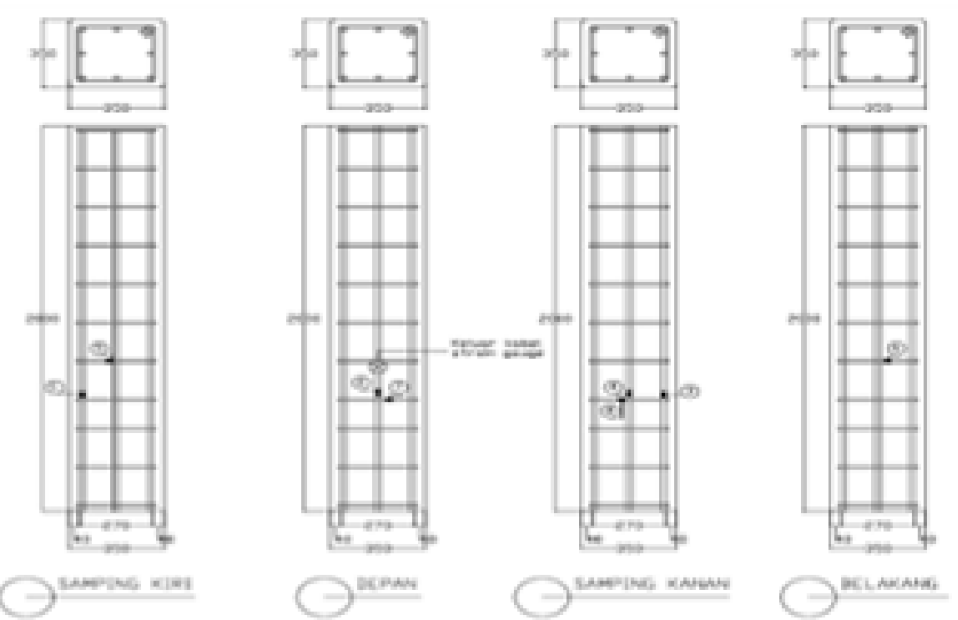

\section{Gambar 6. Penempatan strain gauge tulangan}

\section{Aplikasi FRP}

Aplikasi FRP menggunakan metode Wet Lay$U p$. Untuk menghindari geser dan debonding maka digunakan overlap antar lapisan sepanjang $200 \mathrm{~mm}$. Benda uji kolom yang terbungkus dibiarkan pada suhu kamar selama 4 hari untuk memastikan epoxy telah mengeras sebelum dilakukan pengujian siklik. Hal ini bertujuan untuk mendapatkan kekuatan penuh sebelum pengujian.

\section{Setting up}

Pelaksanaan pengujian dilakukan dengan menempatkan benda uji kolom berdiri tegak pada loading frame. Untuk mendapatkan asumsi yangn diinginkan maka dalam penelitian ini dibuat alat bantu tambahan berupa pelat baja masing-masing diletakan pada dasar kolom, samping kolom dan pada kepala kolom.

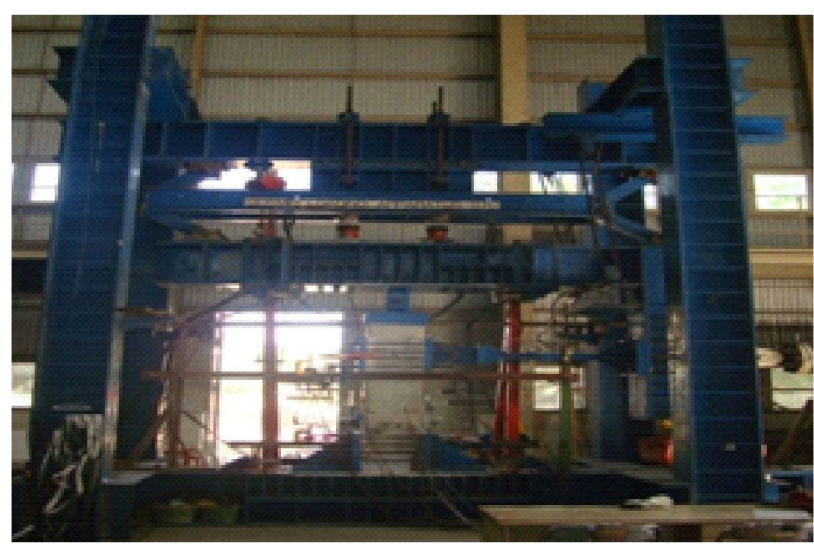

Gambar 7. Set-up pengujian
Deformasi longitudinal diperoleh dari 20 Linear Variable Displacement Transducer(LVDT), masingmasing 10 buah diletakan didaerah sendi plastis, 2 dibagian tengah tinggi efektif kolom, 2 buah diatas, 6 buah dibawah sebagai kontrol alat bantu pelat baja bagian bawah, seperti ditunjukan gambar 8 .

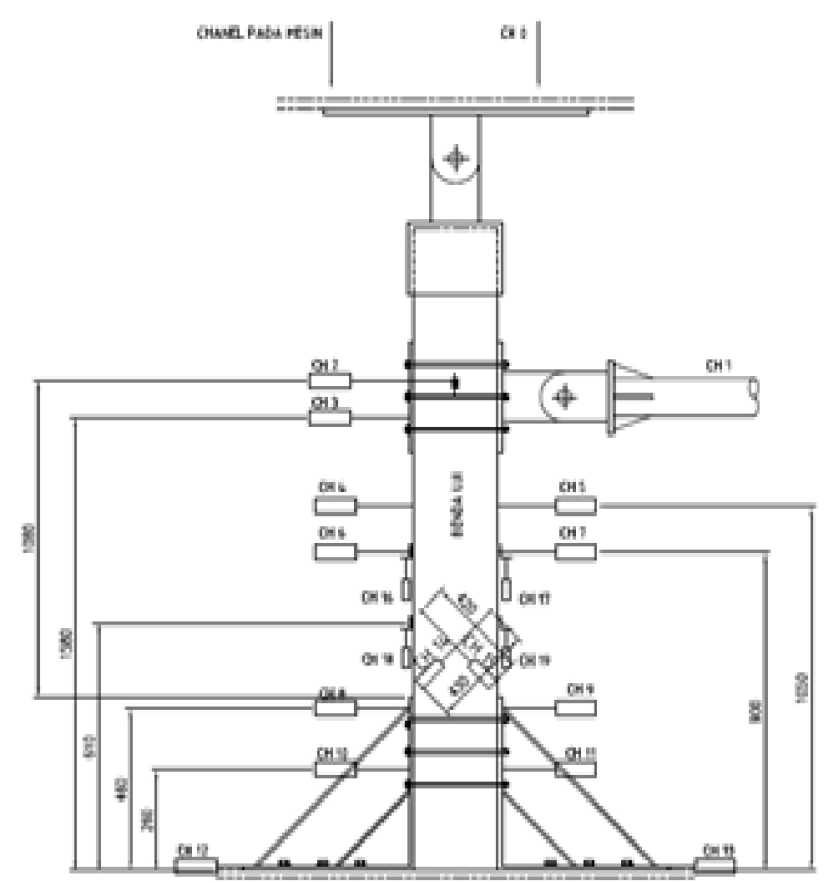

Gambar 8. Aplikasi LVDT

\section{HASIL DAN PEMBAHASAN}

\section{Beban Rencana}

Beban rencana diperoleh dari perhitungan diagram interaksi kolom 


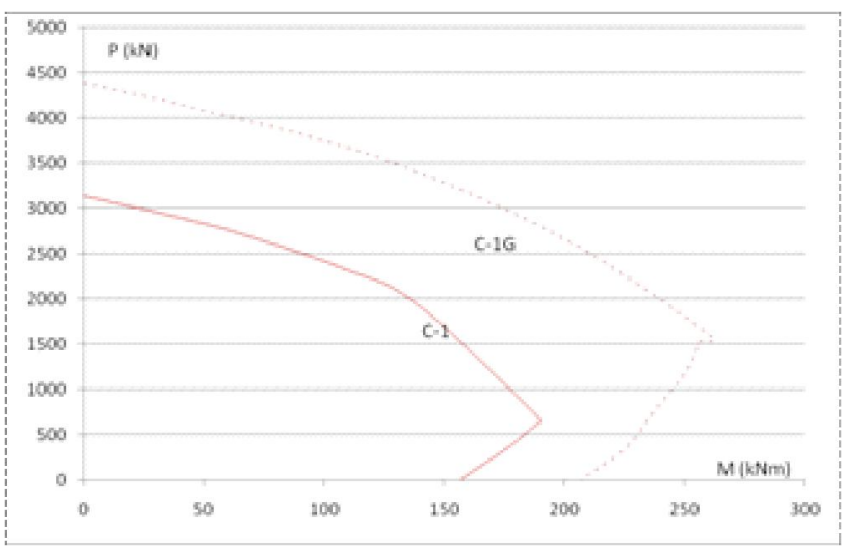

Gambar 9. Diagram Interaksi Specimen

Dari diagram interaksi diperoleh beban aksial konstan sebesar $748 \mathrm{kN}$ dan beban $\mathrm{P}_{\mathrm{H}}$ bervariasi sebesar 181,57 kN dan 217,38 kN masing-masing untuk C-1 dan C-1G

\section{Pelaksanaan Pengujian Siklik}

Pengujian dimulai dengan pemberian beban aksial sesuai dengan perencanaan awal kemudian lateral load diberikan secara bertahap sesuai dengan pola pembebanan ACI 374.1-05 dengan rasio drift D/L (x102): 0,$2 ; 0,25 ; 0,35 ; 0,5 ; 0,75 ; 1,0 ; 1,4 ; 1,75$; 2,20; 2,75 dan 3,5 dan tiga siklus untuk setiap tingkat penyimpangan. Pengujian dihentikan setelah terjadi penurunan beban sampai $20 \%$ dari Pmax dengan target displacement sebesar $54,5 \mathrm{~mm}$.

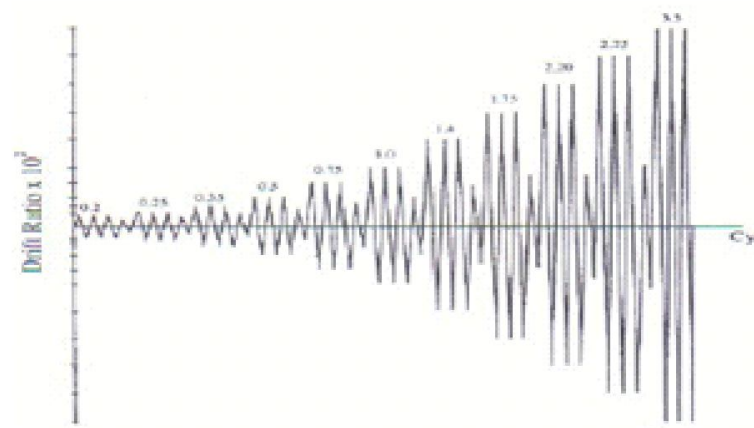

Gambar 10. Pola pembebanan ${ }^{3}$

\section{Kegagalan Specimen}

Kegagalan C-1 akibat spalling beton. Pmax tercapai pada drift 2,75\% siklus pertama dengan nilai $278,9 \mathrm{kN}$. Mulai spalling kolom terjadi tidak lama setelah Pmax tercapai yaitu pada saat beban mencapai $250,1 \mathrm{kN}$ dengan rasio lateral drift yang sama dengan saat tercapai Pmax yaitu 2,75 \% siklus pertama dengan displacement sebesar $28,42 \mathrm{~mm}$. Spalling ini terjadi pada sisi tekan kolom yang menyebabkan tulangan longitudinal terlihat dengan jelas.

Kerusakan C-1 paling parah terjadi pada zona sendi plastis Kegagalan diakibatkan spalling beton dan hancurnya inti beton serta tekuk tulangan longitudinal. Selain di zona sendi plastis, kerusakan juga terjadi pada kolom bagian atas, meskipun tidak sebesar pada zona sendi plastis.

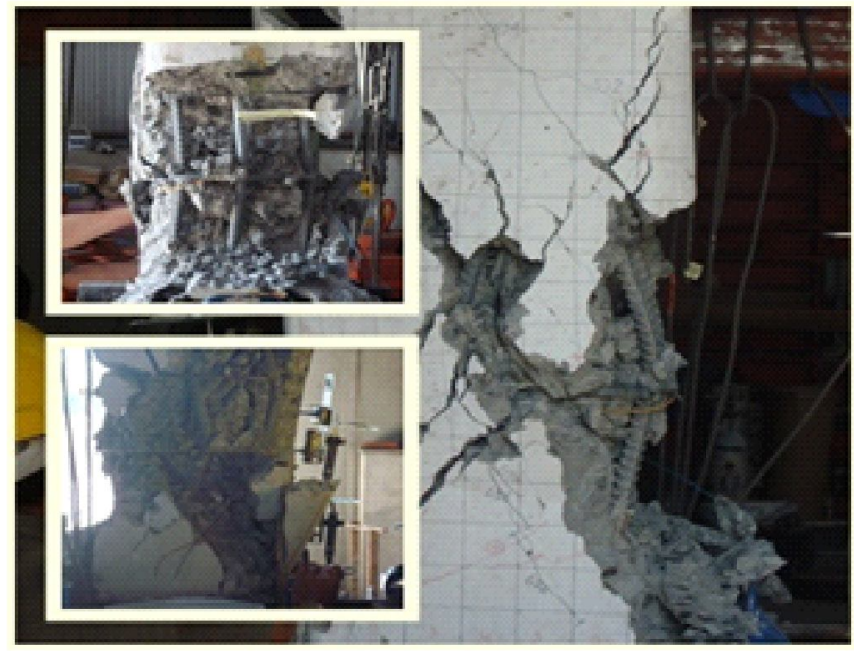

Gambar 11. Kegagalan Kolom C-1

Berbeda dengan $\mathrm{C}-1$, untuk specimen $\mathrm{C}-1 \mathrm{G}$ kegagalan kolom ditandai dengan hancurnya beton dan terjadi kegagalan FRP. Dari hasil pengamatan eksperimental menunjukan bahwa FRP tidak pecah sekaligus namun secara bertahap, yang didahului dengan perubahan warna pada resin. Kegagalan dimulai dari beberapa serat di satu lokasi karena terjadi retak beton. Pada rasio lateral drift 2,75\% siklus ke 2, kepala kolom pecah bersamaan dengan terdengar suara yang nyaring akibat GFRP yang robek. Beton hancur dan GFRP robek dibagian sudut penampang kolom. Beban puncak yang terbaca adalah $372,4 \mathrm{kN}$ dengan displacament sebesar 38,04 mm.

Pengujian dilanjutkan tanpa adanya beban aksial yang mengakibatkan grafik beban lateral munurun secara drastis dan mengakibatkan pada tahap awal pasca hilangnya beban aksial, pola grafik beban displacement menjadi tidak teratur. Ketika beban lateral mencapai $142,6 \mathrm{kN}$ dengan displacement 56,78 mm mulai terlihat kegagalan GFRP pada daerah sendi 
plastis. Hal ini sudah melampaui displacement rencana sebesar $54,5 \mathrm{~mm}$. Kegagalan ini ditandai dengan terjadi perubahan warna pada resin yang semakin lama semakin panjang searah dengan tulangan transversal. Sesuai dengan pola pembebanan yang ada maka pengujian dihentikan pada rasio lateral drift 5\% siklus ke tiga. Pada saat dihentikan kerusakan di daerah zona plastis hanya sampai tahap terjadi perubahan warna pada resin dan kondisi permukaan specimen sudah tidak merata yang menandakan beton didalam GFRP telah mengalami kerusakan namun GFRP belum pecah.

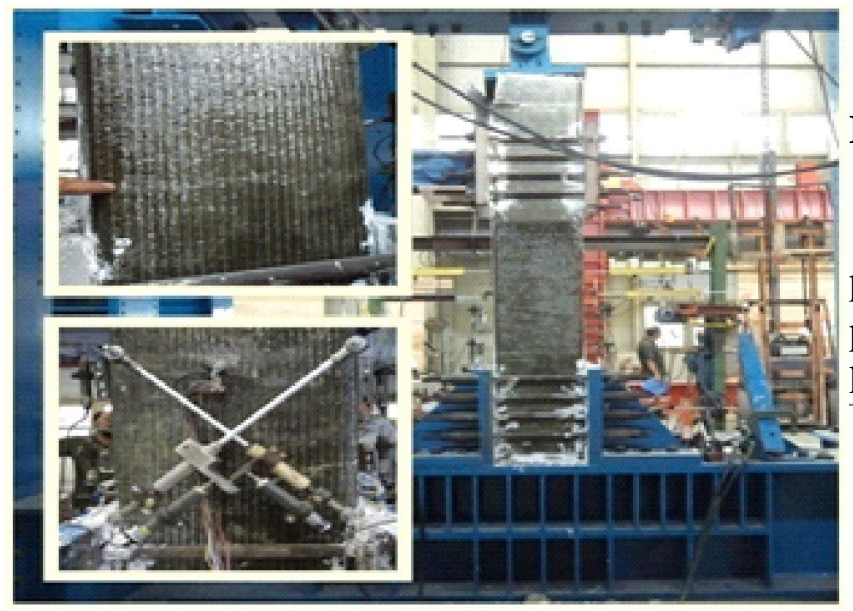

\section{Gambar 12. Kegagalan Kolom C-1G}

Ditemukan dua titik kegagalan pada bagian belakang specimen masing-masing sepanjang 10 dan $11 \mathrm{~cm}$ serta satu titik kegagalan GFRP sepanjang 18 cm dibagian depan specimen.

\section{Beban-Displacement}

Besarnya Pmax yang terjadi adalah $278,9 \mathrm{kN}$ dan $372,4 \mathrm{kN}$ serta dmax yang terjadi adalah 53,24 $\mathrm{mm}$ dan 56,78 $\mathrm{mm}$ masing-masing untuk C-1 dan C-

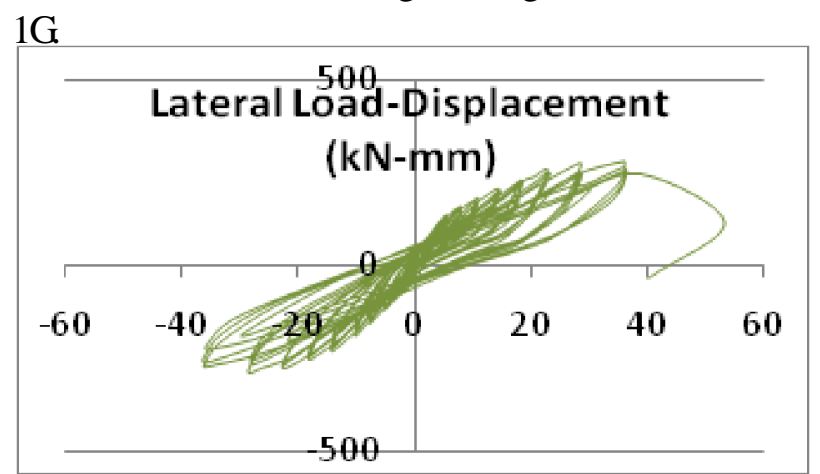

(a)

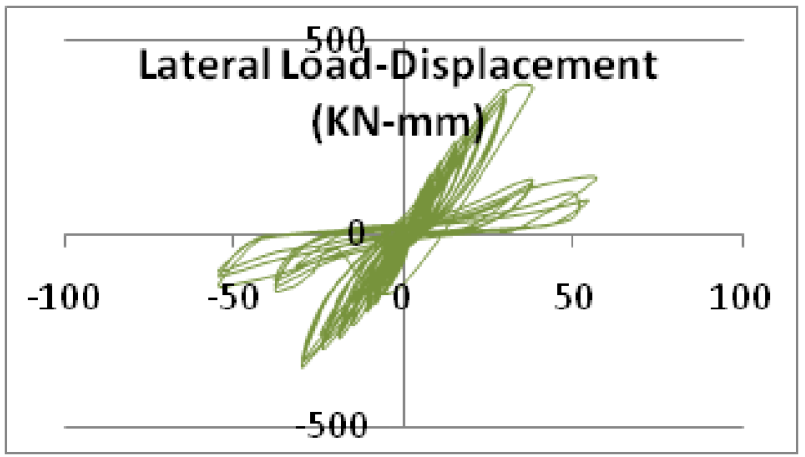

(b)

\section{Gambar 13. Grafik Beban-Displacement: (a)}

$$
\text { C-1; (b) C-1G }
$$

\section{Momen-Curvature}

Dalam penelitian ini akan di ambil indeks daktilitas pada 3 posisi yaitu indeks daktilitas di daerah sendi plastis, di tengah tinggi kolom dan setinggi efektif kolom.

\section{Momen-Curvature}

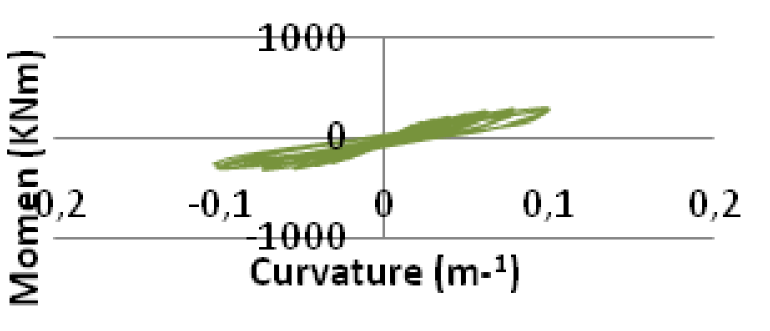

(a)

\section{Momen-Curvature}

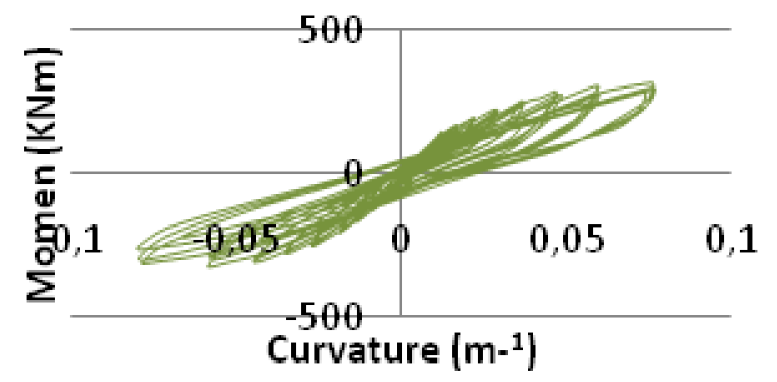

(b) 


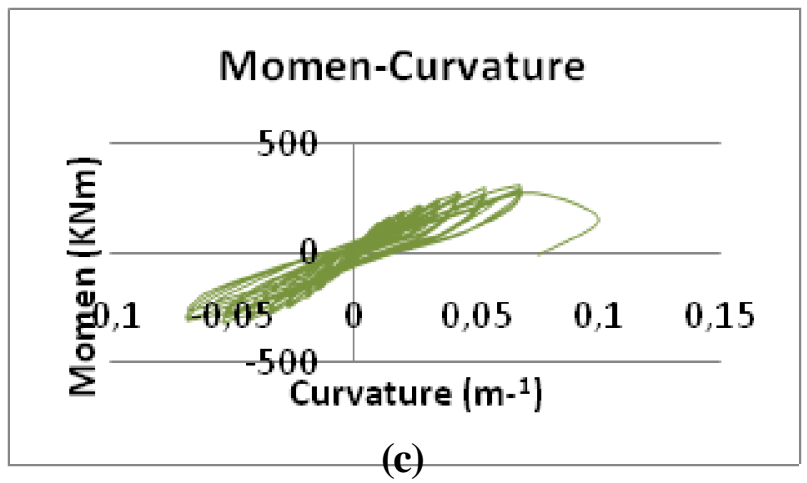

Gambar 14. Grafik Momen-Curvature Specimen C-1 (a) Daerah sendi plastis; (b) Setengah tinggi kolom efektif dan (c) Setinggi efektif kolom

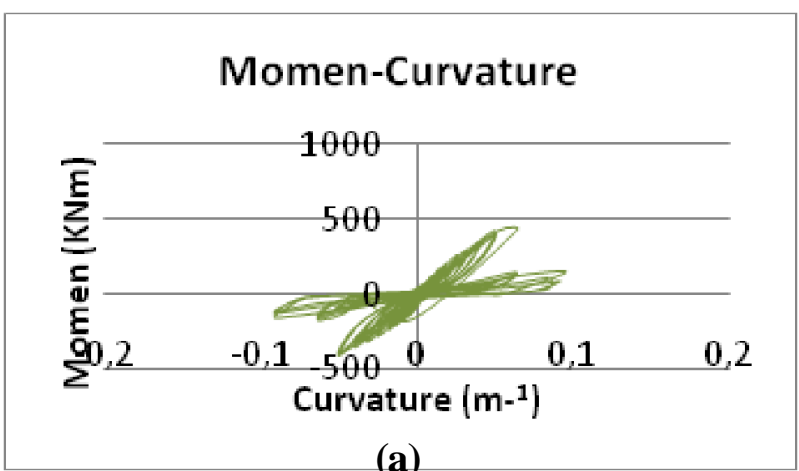

Momen-Curvature

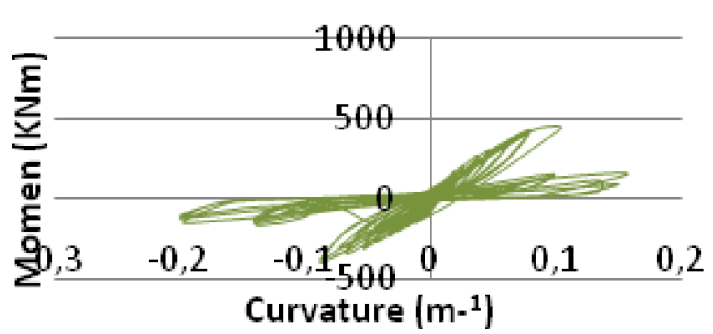

(b)

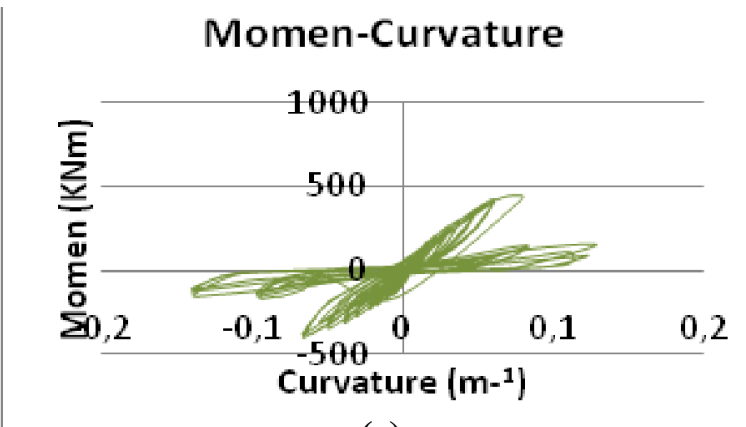

(c)

\section{Gambar 15. Grafik Momen-Curvature} Specimen C-1G (a) Daerah sendi plastis; (b) Setengah tinggi kolom efektif dan (c) Setinggi efektif kolom

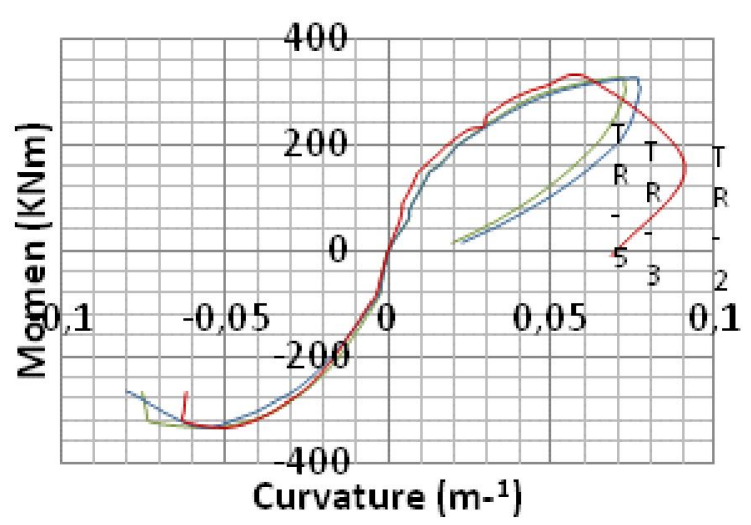

Gambar 16. Skeleton Momen-Curvature Specimen C-1

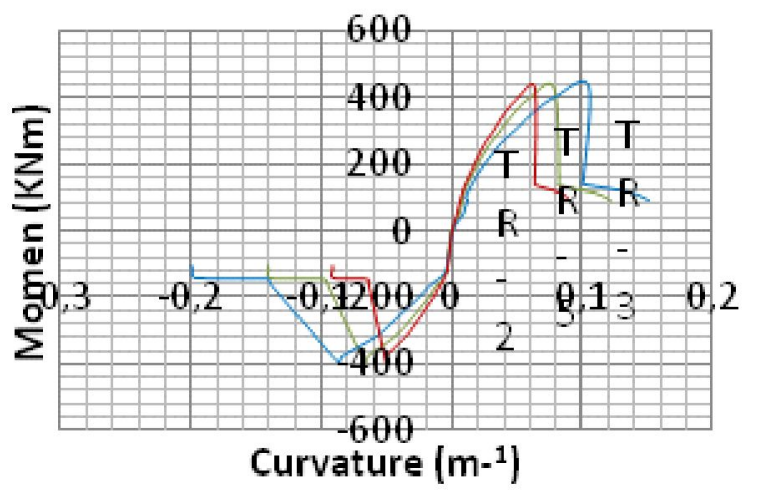

\section{Gambar 17. Skeleton Momen-Curvature Specimen C-1G}

Nilai indeks daktilitas C-1 untuk daerah sendi plastis, setengah tinggi kolom dan setinggi efektif kolom berturut-turut adalah 1,$65 ; 1,71$ dan 1,97. Nilai indeks daktilitas C-1G 1,44; 1,44 dan 1,38. Menurunnya nilai indeks daktilitas $\mathrm{C}-1 \mathrm{G}$ karena kegagalan yang terjadi pada kepala kolom. Momen maksimum pada specimen $\mathrm{C}-1 \mathrm{G}$ adalah $434,37 \mathrm{kNm}$ yang meningkat dari specimen $\mathrm{C}-1$ sebesar $32,41 \%$.

\section{KESIMPULAN DAN SARAN}

1. Kerusakan pada C-1 terpusat pada daerah sendi plastis yang ditandai tulangan longitudinal bengkok dan terjadi spalling selimut beton hingga inti beton terlihat. Pada kolom C-1G sampai dengan rasio lateral drift yang diacu yaitu 5\% siklus terakhir di zona sendi plastis terjadi perubahan warna pada resin dan kondisi permukaan specimen sudah tidak merata yang menandakan beton didalam GFRP telah mengalami kerusakan namun GFRP belum pecah. Ditemukan dua titik kegagalan di zona 
sendi plastis yaitu bagian belakang specimen masing-masing sepanjang 10 dan $11 \mathrm{~cm}$ serta satu titik kegagalan GFRP sepanjang $18 \mathrm{~cm}$ dibagian depan specimen.

2. Besarnya Pmax adalah $278,9 \mathrm{kN}$ dan $372,4 \mathrm{kN}$ serta dmax yang terjadi adalah 53,24 mm dan $56,78 \mathrm{~mm}$ masing-masing untuk C-1 dan C-1G. Meski terjadi kegagalan kepala kolom, peningkatan Pmax C-1G mencapai 33,63\% dan dmax C-1G mencapai 6,65\% terhadap C-1

3. Nilai Mmax C-1 dan C-1G adalah $328,04 \mathrm{kNm}$ dan 434,37 kNm. Peningkatan Mmax C-1G sebesar 32,41\% terhadap C-1.

4. Indeks daktilitas C-1 untuk daerah sendi plastis, setengah tinggi kolom dan setinggi efektif kolom berturut-turut adalah 1,$65 ; 1,71 ; 1,97$ dan C-1G adalah 1,$44 ; 1,44 ; 1,38$. Menurunnya daktilitas C-1G akibat terjadi kegagalan kepala kolom saat pengujian berlangsung.

\section{Ucapan Terimakasih}

Penulis mengucapkan terima kasih kepada FYFE Co. LLC Singapore dengan perwakilan di Indonesia adalah PT. Fyfe Fibrwrap Indonesia dan PT. Master Solusi Indonesia (MSI) atas bantuan dan kerjasamanya dalam menyediakan material GFRP (Tyfo ${ }^{\circ}$ Fibrwrapò Composite Systems) dan applicatornya.

\section{DAFTAR PUSTAKA}

ACI 440.2R-02. "Guide for the Design and Construction of Externally Bonded FRP Systems for Strengthening Concrete Structures". ACI Committee 440, 2002.

ACI 440.3R-04. "Guide Test Methods for FiberReinforced Polymers (FRPs) for Reinforcing or Strengthening Concrete Structures". ACI Committee 440, 2004.

ACI 374.1-05. "Acceptance Criteria for Moment Frames Based on Structural Testing and Commentary”. ACI Committee 374, 2005.
Al-Sulayfani, B and Al-Taee, H. "Modeling of StressStrain Relationship for Fibrous Concrete Under Cyclic Loads" Eng.Tech.Vol.26, No1, 2008, pp. 45-53.

Balaguru, P, Nanni, A and Giancaspro, J. "FRP Composites for Reinforced and Prestressed Concrete Structures" Taylor \& Francis Group, New York, 2009.

Bank, Lawrence. "Structural Design with FRP Materials" John Wiley \& Sons, INC, Canada, 2006.

Benzaid, R, Chikh NE and Mesbah H. "Behaviour Of Square Concrete Column Confined With GFRP Composite Warp", Journal Of Civil Engineering And Management, 2008.

Cole, C. and Belarbi, A. "Confinement Characteristics of Rectangular FRPJacketed RC Columns", Proceedings of the Fifth International Symposium on Fiber Reinforced Polymer for Reinforced Concrete Structures (FRPRCS-5), Cambridge, UK, July 16-18, 2001, pp. 823-832.

Gangarao, H, Taly, N and Gangarao, H. "Reinforced Concrete Design with FRP Composites" CRC Press, Prancis, 2007.

Lee, Chung-Sheng, Hegemier, GA and Philippi DJ. "Analitical Model for Fiber Reinforced Polymer Jacketed Square Concrete Columns in Axial Compression" ACI Structural Journal, 2010 pp.208-217.

Nawy, Edward. "Beton Bertulang Suatu Pendekata Dasar" PT. Refika Aditama, Bandung, 2008.

Nurlina, Siti. "STRUKTUR BETON" Penerbit BARGIE Media, Malang, 2008.

Panitia Teknik Standardisasi Bidang Konstruksi dan Bangunan. "Tata Cara Perhitungan Struktur Beton Untuk Bangunan Gedung (SNI 032847-2002)". Badan Standardisasi Nasional. Bandung, 2002. 
Park, R and Paulay,T."Reinforced Concrete Structures" John Wiley and Sons, Canada, 1975.

Rousakis, T and Tepfers, R. "Behavior of Concrete Confined by High E-Modulus Carbon FRP Sheets, Subjected to Monotonic and Cyclic Axial Compressive Load".

Saadatmanesh, H, Ehsani, MR and Li, MW. "Strength and Ductility of Concrete Columns Externally Reinforced with Fiber Composite Straps" ACI Structural Journal, 1994.

Sheikh, SA and Liu, J. "Enhancing Seismic resistance of Concrete Columns with FRP" Proceedings fib Symposium PRAGUE, 8-10 June 2010.

Sheikh, SA and Yau, G. "Seismic Behavior of Concrete Columns Confined with Steel and Fiber-Reinforced Polymers" ACI Structural Journal, January-February 2002, pp. 72-80.

Tavio dan Kusuma, B. "Studi Analisis Pengaruh Pengekangan Terhadap Kapasitas Interaksi P-M Tiang Pancang Prategang", Konferensi Nasional Teknik Sipil 4, Bali, 2-3 Juni 2010 hal. 349-356.

Watanabe, K, Niwa, J, Yokota, H and Iwanami, M. "Stress-Strain Relationship for the Localized Compressive Failure Zone of Concrete under Cyclic Loading". 